\title{
KINERJA MIKROBA Zymomonas mobilis DAN Saccharomyces cerevisiae UNTUK MENGURAIKAN HIDROLISAT TONGKOL JAGUNG MENJADI BIOETANOL DENGAN PENGARUH WAKTU FERMENTASI DAN RASIO PENAMBAHAN MIKROBA
}

\author{
PERFORMANCE OF MICROBES Zymomonas mobilis AND Saccharomyces cerevisiae TO \\ CHANGE OF HYDROLYSIS OF CORN COBS INTO BIOETHANOL BY THE \\ INFLUENCE OF FERMENTATION TIME AND THE RATIO OF THE ADDITION OF \\ MICROBES
}

\author{
Fatimah*, Deralisa Ginting, Veronica Sirait \\ Departemen Teknik Kimia, Fakultas Teknik Universitas Sumatera Utara, Sumatera Utara \\ Jl. Almamater Kampus USU Medan 20155, Indonesia \\ *E-mail : fatimahagussalim@yahoo.com
}

\begin{abstract}
Abstrak
Bioetanol yang berasal dari biomassa merupakan salah satu bentuk energi yang memiliki potensi sebagai bahan bakar alternatif. Bioetanol dapat diproduksi dengan menggunakan jamur ataupun bakteri. Penelitian tentang kinerja mikroba Zymomonas mobilis dan Saccharomyces cerevisiae untuk menguraikan hidrolisat tongkol jagung menjadi bioetanol dengan pengaruh waktu fermentasi dan rasio penambahan mikroba telah selesai dilakukan. Hidrolisat yang digunakan diperoleh dari hidrolisis tongkol jagung dengan menggunakan mikroba Trichoderma reesei dan Aspergillus niger. Tujuan penelitian ini adalah untuk mempelajari kinerja dari campuran Zymomonas mobilis dan Saccharomyces cerevisiae dalam mengubah hidrolisat (glukosa) menjadi bioetanol pada berbagai variasi waktu fermentasi (1 hari, 3 hari, 5 hari, dan 7 hari) dan rasio penambahan mikroba (Zymomonas mobilis : Saccaromyces cerevisiae $=1: 1 ; 1: 2$ dan 2:1) (v/v). Kandungan glukosa awal pada hidrolisat tongkol jagung sebesar $5,869 \mathrm{~g} / \mathrm{ml}$. Fermentasi berlangsung pada suhu $25{ }^{0} \mathrm{C}$. Bioetanol yang diperoleh kemudian dianalisis dengan menggunakan kromatografi gas. Yield bioetanol tertinggi diperoleh sebesar 6,31 \% dengan menggunakan perbandingan Zymomonas mobilis : Saccharomyces cerevisiae (2:1) pada waktu fermentasi 3 hari.
\end{abstract}

Kata kunci: Bioetanol, Hidrolisat Tongkol Jagung, Saccharomyces cerevisia, Zymomonas mobilis

\begin{abstract}
Bioethanol from biomass is one of energy which has a potential as alternative fuel. Bioethanol can be produced by using fungi or bacteria. The research was about the performance of Zymomonas mobilis and Saccharomyces cerevisiae to change corn cobs hydrolyzate into bioethanol by adding microbes to the influence of time and ratio of fermentation had been done. The hydrolyzate were decomposition of corn cobs using Trichoderma reesei and Aspergillus niger. The purpose of this study was to know the conversion of hydrolysis of corn cobs into bioethanol with variation time of fermentation (1 day, 3 days, 5 days, and 7 days) and rate of adding microbes (Zymomonas mobilis : Saccharomyces cerevisiae $=1: 1 ; 1: 2$ and 2:1) $(\mathrm{v} / \mathrm{v})$. The glucose from corn cobs hydrolyzate was $5,869 \mathrm{~g} / \mathrm{ml}$. Fermentation wass carried out at $25^{\circ} \mathrm{C}$. Bioethanol which obtained from this study was investigated using gas chromatography. The optimum bioethanol yield was equal to 6,31\% by using Zymomonas mobilis : Saccharomyces cerevisiae (2:1) and at the 3 days fermentation time.
\end{abstract}

Keywords: Bioethanol, Corn Cobs Hydrolysis, Saccharomyces cerevisiae, Zymomonas mobilis

\section{Pendahuluan}

Bioetanol yang berasal dari biomassa merupakan salah satu bentuk energi yang memiliki potensi sebagai bahan bakar alternatif [15]. Salah satu biomassa yang dapat dijadikan bioetanol adalah tongkol jagung. Kandungan selulosa pada tongkol jagung yang cukup tinggi yaitu $48 \%$, memungkinkan dapat dimanfaatkan sebagai bahan baku pembuatan bioetanol. Tongkol jagung di Indonesia tersedia dalam jumlah yang banyak, diperkirakan setiap panen jagung terdapat $30 \%$ berupa limbah tongkol jagung [11].

Bioetanol dari tongkol jagung menjalani proses hidrolisis menjadi glukosa (hidrolisat) terlebih dahulu kemudian diuraikan dengan proses fermentasi menjadi bioetanol. Hidrolisis selulosa 
salah satu tahapan penting karena proses hidrolisis dapat menentukan jumlah glukosa yang dihasilkan [19].

Produksi bioetanol dari tanaman yang mengandung lignin dan pati atau karbohidrat, dapat dilakukan melalui konversi karbohidrat menjadi gula atau glukosa dengan beberapa metode diantaranya dengan pretreatment dan hidrolisis secara enzimatik. Pada penelitain sebelumnya pembuatan bioetanol dari bagasse menggunakan Saccharomyces cerevisiae dan Zymomonas mobilis dilakukan dengan 4 tahap yaitu pretreatment, hidrolisis enzim fermentasi dan destilasi. Tahapan tersebut menghasilkan bioetanol terbaik dengan menggunakan campuran kedua mikroba pada waktu fermentasi 4 hari. [23]. Pembuatan bioetanol dari tongkol jagung menggunakan Zymomonas mobilis memperoleh hasil terbaik dengan menggunakan hidrolisis asam $\left(\mathrm{HClO}_{4}\right)$ dan pada waktu fermentasi 5 hari [4]. Penelitian pembuatan bioetanol dari eceng gondok dengan menggunakan Saccharomyces cerevisiae dan Zymomonas mobilis memperoleh hasil terbaik dengan melakukan proses pretreatment pemanasan, kemudian likuifikasi dengan A.niger. Diperoleh hasil bioetanol terbaik dengan menggunakan Saccharomyces cerevisiae saja pada waktu fermentasi 5 hari [6].

Berdasarkan uraian diatas, Penelitian ini akan menggunakan Saccharomyces cerevisiae dan Zymomonas mobilis sebagai penghasil etanol dengan waktu fermentasi yang divariasikan. Dengan campuran ini diharapkan fermentasi yang dilakukan lebih efisien dibandingkan menggunakan satu jenis mikroba.Penggunaan kedua mikroba tersebut diharapkan dapat meningkatkan yield bioetanol.

\section{Teori}

Limbah lignoselulosik adalah limbah pertanian yang mengandung selulosa, hemiselulosa, dan lignin. Tongkol jagung merupakan salah satu limbah lignoselulosik yang banyak tersedia di Indonesia. Produksi jagung dapat bertambah setiap tahunnya. Pertambahan produksi jagung ini disebakan oleh adanya kenaikan luas panen seluas 16,51 ribu hektar dapat meningkatkan produksi sebanyak 0,43\% serta peningkatan produktivitas sebesar 1,15 kuintal/hektar dapat meningkat sebesar 2,37 \% terhadap tumbuhan jagung. Pada tahun 2014 diperoleh sebanyak 19,03 juta ton pipilan kering. Jumlah ini mengalami kenaikan sebanyak 0,52 juta ton $(2,81 \%)$ dibandingkan tahun 2013 [16].

Bioetanol adalah etanol yang diproduksi dengan cara fermentasi gula menggunakan ragi [8]. Produksi bioethanol dapat dilakukan dengan beberapa metode, diantaranya adalah dengan pretreatment bahan baku, hidrolisis dan fermentasi [22]. Pretreatment biomassa bertujuan untuk meningkatkan area permukaan selulosa, sehingga dapat meningkatkan konversi selulosa menjadi glukosa [5]. Hidrolisis merupakan proses pemecahan polisakarida dalam lignoselulosa menjadi monomer gula penyusunnya [22]. Hidrolisis enzimatik memiliki kelebihan yaitu kondisi proses yang lebih lunak (suhu rendah dan $\mathrm{pH}$ netral) dan tidak terjadi degradasi gula hasil hidrolisis [11]. Enzim yang dapat menghidrolisis selulosa ialah selulase. Enzim selulase dalam hidrolisis selulosa berperan dalam memecah ikatan $\beta$-1,4-D-glikosida, cellobiohyrolases dan $\beta$ glucosidases untuk menghasilkan glukosa. Enzim selulase dapat diproduksi dari kapang ataupun bakteri [3]. Trichoderma reesei dan Aspergillus niger merupakan jenis kapang penghasil enzim selulase yang sangat efesien dalam memproduksi enzim selulase [18]. Fermentasi adalah proses terjadinya dekomposisi gula menjadi alcohol dan karbondioksida $\left(\mathrm{CO}_{2}\right)$. Berdasarkan produk yang dihasilkan, fermentasi digolongkan menjadi dua macam, yaitu Fermentasi alkoholis dan Fermentasi nonalkoholis. Fermentasi alkoholis adalah fermentasi yang menghasilkan alkohol sebagai produk akhir, sedangkan fermentasi nonalkoholis adalah fermentasi yang tidak menghasilkan alcohol sebagai produk akhir [6]. Saccharomyces cerevisiae dan Zymomonas mobilis merupakan jenis jamur dan bakteri yang dapat menghasilkan etanol [2]. Saccharomyces cerevisiae dapat mengubah glukosa, manosa dan galaktosa menjadi etanol [21]. Zymomonas mobilis dapat mengubah glukosa, sukrosa, dan fruktosa menjadi etanol [12]. Perpaduan antara Saccharomyces cerevisiae dan Zymomonas mobilis menunjukkan keseimbangan terbaik dalam mengubah glukosa menjadi bioetanol.

Reaksi yang terjadi pada proses produksi bioetanol secara sederhana ditunjukkan pada reaksi berikut [17]:

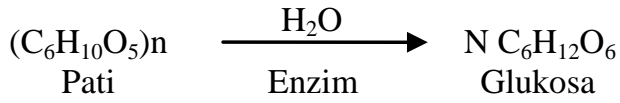

$$
\begin{aligned}
& \text { Yeast (ragi) } \\
& \underset{\text { Glukosa }}{\left(\mathrm{C}_{6} \mathrm{H}_{12} \mathrm{O}_{6}\right) \mathrm{n}} \longrightarrow \underset{\text { Etanol }}{2 \mathrm{C}_{2} \mathrm{H}_{5} \mathrm{OH}+2 \mathrm{CO}_{2}}
\end{aligned}
$$

\section{Metodologi Penelitian \\ Bahan Baku dan Mikroba}

Bahan baku yang digunakan dalam penelitian ini adalah hidrolisat tongkol jagung yang digunakan sebagai glukosa. Volume hidrolisat yang digunakan untuk pembuatan bioetanol yaitu sebanyak $50 \mathrm{ml}$. Mikroorganisme 
Zymomonas mobilis yang digunakan diperoleh dari Lab Pangan dan Gizi UGM dan Saccharomyces cerevisiae diperoleh dari Lab Mikrobiologi IPB.

\section{Pembenihan Isolat}

Penelitian ini diawali dengan pembiakan mikroba Zymomonas mobilis dan Saccharomyces cerevisiae dengan menggunakan media PDA (Potato Dextrose Agar). Tujuan pembiakan mikroba adalah untuk memperoleh mikroba yang siap digunakan untuk proses fermentasi. Indikasi mikroba siap yang digunakan dapat dilihat secara visual dalam cawan petri [2]. Selanjutnya, mikroba yang tumbuh dalam media PDA diinkubasi dalam $100 \mathrm{ml}$ media cair yang terdiri dari $22 \%$ sukrosa, $1 \% \quad\left(\mathrm{NH}_{4}\right)_{2} \mathrm{SO}_{4}$ dan $1 \%$ $\mathrm{KH}_{2} \mathrm{PO}_{4}$ pada $\mathrm{pH}$ 5. Inokulum Zymomonas mobilis dan Saccharomyces cerevisiae diambil dengan kawat ose lalu dicelupkan beberapa saat pada media cair hingga tampak keruh. Media cair ditutup dan diinkubasi selama 48 jam pada $20^{\circ} \mathrm{C}$.

\section{Prosedur Fermentasi}

Proses fermentasi yang dilakukan pada penelitian ini yaitu dengan proses anerobik. Hidrolisat tongkol jagung sebanyak $50 \mathrm{ml}$ dimasukkan kedalam Erlenmeyer $250 \mathrm{ml}$. Inokulum cair Zymomonas mobilis dan Saccharomyces cerevisiae dimasukkan secara bersamaan dengan perbandingan 1:1, 1:2 dan 2:2 (v/v). Cairan difermentasikan pada suhu ruangan dengan waktu yang divariasikan yaitu 1 hari, 3 hari, 5 hari, dan 7 hari. Hasil fermentasi disaring menggunakan kertas saring. Biotanol yang diperoleh diukur densitas, $\mathrm{pH}$, viskositas serta kadar bioetanol yang dihasilkan dengan dengan menggunakan kromotografi gas di Pusat Penelitian Kelapa Sawit, Sumatera Utara, Medan.

\section{Analisis Kimia \\ Kandungan Glukosa, Densitas, Viskositas, dan Kadar Etanol \\ Kandungan glukosa hidrolisat tongkol jagung dianalisis dengan menggunakan Spektrofotometer UV-Vis. Analisis densitas dan viskositas menggunakan instrumen Viscosimeter Ostwald di Laboratorium Penelitian, Departemen Teknik Kimia, Fakultas Teknik, Universitas Sumatera Utara, Medan. Analisis kadar etanol dilakukan dengan menggunakan Gas Chromatography (GC).}

\section{Hasil dan Pembahasan \\ Hasil Analisis Bahan Baku}

Hidrolisat tongkol jagung yang diperoleh memiliki kadar awal gula reduksi (glukosa awal) hidrolisat tongkol jagung yaitu sebesar 5,869 g/ml serta volume hidrolisat yang dihasilkan sebanyak $50 \mathrm{ml}$.

\section{Pertumbuhan Mikroba}

Pertumbuhan mikroba dilihat dari hasil pembiakan yang telah dilakukan didalam cawan petri. Pertumbuhan Saccharomyces cerevisiae dan Zymomonas mobilis tentu tidak sama, karena kedua mikroba tersebut merupakan mikroba dengan kingdom yang berbeda. Saccharomyces cerevisiae berasal dari kingdom fungi yang secara morfologi tumbuh berbentuk blastospora berbentuk bulat lonjong, silindris, oval atau bulat telur yang dipengaruhi oleh strainnya (Gambar 1a) [23]. Sedangkan Zymomonas mobilis berasal dari kingdom bakteri yang tumbuh menyebar dan tidak beraturan hingga memenuhi cawan (Gambar 1b) [4].

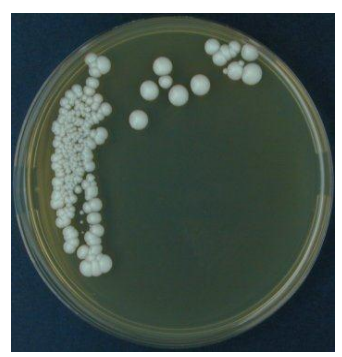

(a)

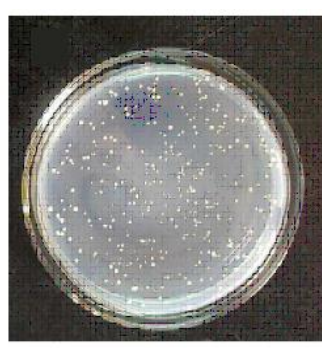

(b)
Gambar 1. (a) Saccharomyces cerevisiae;

(b) Zymomonas mobilis

\section{Pengaruh Waktu Fermentasi Terhadap Yield Bioetanol}

Waktu fermentasi mempengaruhi yield bioetanol yang dihasilkan. Penelitian ini dilakukan dengan variasi waktu fermentasi untuk memperoleh waktu fermentasi terbaik dalam memproduksi bioetanol. Gambar 2 menampilkan grafik pengaruh waktu fermentasi terhadap yield bioetanol pada berbagai perbandingan mikroba.

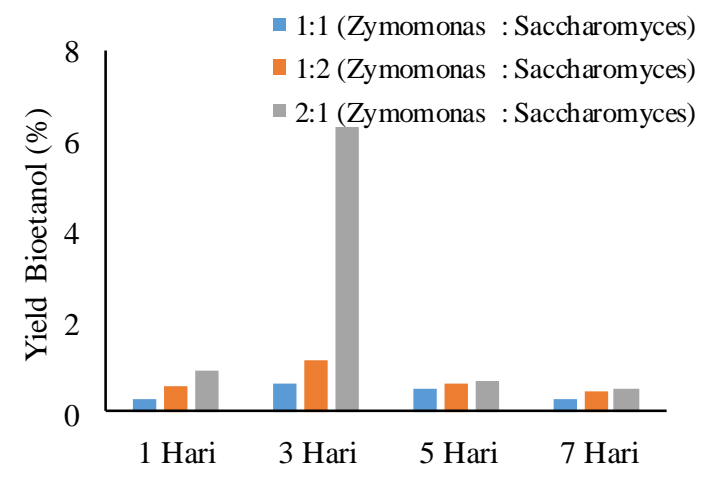

Gambar 2. Pengaruh Waktu Fermentasi Terhadap Yield Bioetanol 
Dari gambar 2 diperoleh bahwa kadar bioetanol pada setiap perbandingan mikroba mengalami kenaikan dan penurunan. Pada gambar di atas, pada waktu fermentasi 1 hari diperoleh yield bioetanol sebesar 0,283\%; $0,55 \%$ dan $0,907 \%$ pada masing-masing perbandingan mikroba. Namun, pada waktu fermentasi hari ke-3 produksi bioetanol mengalami peningkatan pada tiap perbandingan yaitu $0,641 \% ; 1,161 \%$ dan $6,311 \%$. Setalah mengalami peningkatan pada waktu fermentasi 3 hari, yield bioetanol kemudian mengalami penurunan pada waktu fermentasi 5 hari yaitu menjadi $0,499 \%$; $0,643 \%$ dan $0,669 \%$. Pada 7 hari yield bioetanol tetap mengalami penurunan yaitu menjadi $0,258 \% ; 0,428 \%$ dan $0,478 \%$ pada masing-masing perbandingan mikroba.

Menurut teori, ada beberapa faktor yang mempengaruhi yield bioetanol diantaranya pengaruh lama fermentasi. Semakin lama fermentasi berlangsung maka etanol yang dihasilkan juga akan semakin bertambah [18]. Pada waktu fermentasi 3 hari diperoleh yield bioetanol mengalami peningkatan. Hal ini disebabkan karena semakin lama waktu fermentasi semakin banyak pula waktu yang dibutuhkan oleh mikroba untuk mengurai gula menjadi etanol, sehingga etanol yang dihasilkan semakin meningkat. Setelah waktu fermentasi hari ke-3, bioetanol mengalami penurunan. Penurunan yield bioetanol dari hari ke-5 hingga hari ke-7 ini memungkin gula yang terdapat didalam larutan sebagian besar telah diurai menjadi etanol, sehingga aktivitas mikroba akan berkurang karena kekurangan gula sebagai makanan yang akan diurai menjadi bioetanol [16]. Pada gambar 2 diperoleh produksi bioetanol tertinggi pada waktu fermentasi 3 hari. Jika fermentasi dilakukan lebih dari 3 hari maka produksi bioetanol akan mengalami penurunan.

\section{Pengaruh Waktu Fermentasi Hidrolisat Tongkol Jagung Terhadap Gula Reduksi Sisa}

Gula reduksi ialah gula yang mempunyai kemampuan untuk mereduksi gula sederhana menjadi bioetanol dengan pemanfaat mikroba [7]. Penurunan ataupun kenaikan yield bioetanol pada fermentasi dipengaruhi pada konsentrasi gula sisa yang dihasilkan. Kadar gula reduksi awal sebesar $5,869 \mathrm{~g} / \mathrm{ml}$. Gambar 3 menampilkan grafik pengaruh waktu fermentasi terhadap gula reduksi pada berbagai perbandingan mikroba.

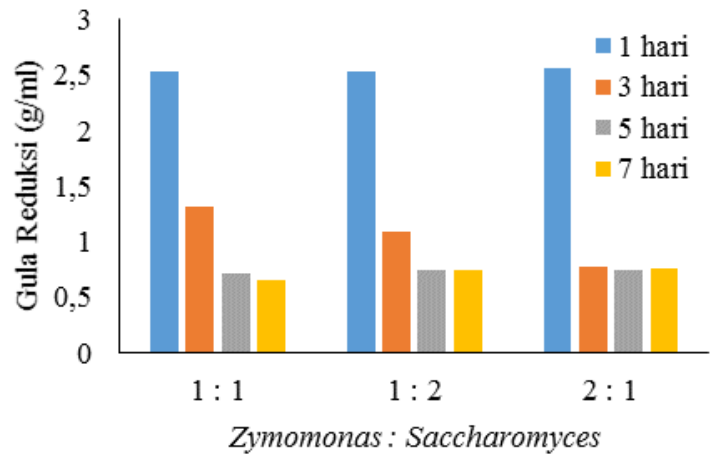

\section{Gambar 3. Pengaruh Waktu Fermentasi Terhadap Gula Reduksi Sisa}

Pada gambar 3 di atas menunjukkan bahwa adanya hasil analisis beragam terhadap konsentrasi sisa gula reduksi. Hal ini menunjukkan bahwa pengaruh lama fermentasi terhadap konsentrasi gula reduksi sisa. Pada masing-masing gambar menunjukan bahwa konsentrasi gula tereduksi pada hari ke-1 yaitu sebesar 2,528 $(\mathrm{g} / \mathrm{ml})$ pada $1: 1 ; 2,539(\mathrm{~g} / \mathrm{ml})$ pada 1:2 dan 2,559 pada 2:1. Dari hari ke-3 mengalami penurunan yaitu menjadi $1,308(\mathrm{~g} / \mathrm{ml})$ pada $1: 1$; $1,096(\mathrm{~g} / \mathrm{ml})$ pada $(1: 2)$ dan $0,767(\mathrm{~g} / \mathrm{ml})$ pada $2: 1$. Pada hari ke- 5 tetap terjadi penurunan hingga pada hari ke -7 konsentrasi sisa gula terduksi.

Konsentrasi gula reduksi pada hari ke-1 tidak jauh berbeda pada masing-masing perbandingan mikroba. Pada hari ke-3 hingga hari ke-5 juga penuruan gula reduksi sisa tidak berbeda jauh pada masing-masing perbandingan. Semakin lama waktu fermentasi maka semakin banyak gula reduksi awal dimanfaatkan oleh mikroba maka makin tinggi pula produksi bioetanol yang diperoleh dan sebaliknya makin rendah gula reduksi yang dimanfaatkan oleh mikroba maka makin rendah pula produksi bioetanol yang dihasilkan [7]. Hal ini disebabkan karena adanya proses aktivitas mikroba yang berbeda-beda pada masing-masing waktu fermentasi dalam memecahkan monosakarida menjadi gula-gula sederhana [1]. Pada gambar 3 diperoleh gula reduksi sisa yang paling rendah yaitu pada penggunaan mikroba 2:1. Semakin tinggi konsentrasi substrat atau gula reduksi yang dapat dipecah oleh sel mikroba menjadi etanol maka semakin tinggi pula perolehan etanol yang dihasilkan.

\section{Pengaruh Rasio Penambahan Mikroba Terhadap Yield Bioetanol}

Rasio penambahan mikroba berpengaruh terhadap yield bioetanol pada berbagai variasi waktu fermentasi. Ada dua mikroba yang digunakan yaitu Zymomonas mobilis dan 
Saccharomyces cerevisiae. Gambar 4 menampilkan grafik pengaruh rasio penambahan mikroba terhadao yield bioetanol.

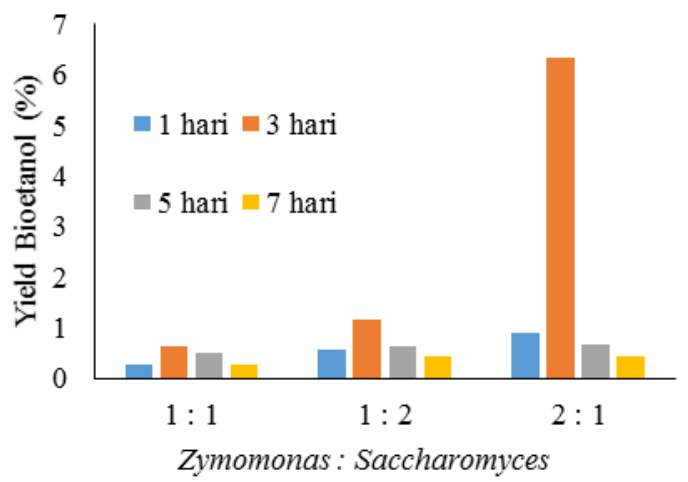

Gambar 4. Pengaruh Rasio Penambahan Mikroba Terhadap Yield Bioetanol

Pada gambar di atas dapat dilihat bahwa yield biotanol yang dihasilkan semakin meningkat pada masing-masing rasio penambahan mikroba. Pada gambar diperoleh yield bioetanol pada rasio penambahan mikroba 1:1 (Zymomonas: Saccharomyces) (v/v) sebesar 0,283\%; 0,641\%; $0,499 \%$ dan $0,258 \%$ pada waktu fermentas 1 hari, 3 hari, 5 hari, dan 7 hari. Pada rasio penambahan mikroba 1: 2 (Zymomonas : Saccharomyces) (v/v) diperoleh peningkatan yield bioetanol yaitu menjadi $0,557 \% ; 1,161 \% ; 0,643 \%$; dan $0,428 \%$ pada masing-masing variasi waktu fermentasi. Pada rasio penambahan mikroba 2:1 (Zymomonas: Saccharomyces) (v/v) yield bioetanol tetap mengalami kenaikan yaitu menjadi 0,907\%; $6,311 \% ; 0,669 \%$; dan 0,473\%. Peningkatan yield biotanol berpengaruh pada lama waktu fermentasi dan jumlah mikroba. Jumlah mikroba dapat ditentukan dengan laju pertumbuhannya [20].

Menurut teori, mikroba Saccharomyces cerevisiae pada fermentasi hari ke-3 tumbuh hanya sedikit dikarenakan Saccharomyces cerevisiae masih dalam fase lag. Fase lag merupakan fase dimana mikroba masih beradaptasi untuk tumbuh dan menyesuaikan diri. Pada fermentasi 5 hari dan 7 hari jumlah mikroba sudah semakin banyak [14]. Sedangkan, pada bakteri Zymomonas mobilis memiliki pertumbuhan yang berbeda. Bakteri Zymomonas mobilis mengalami empat fase diantaranya fase lag dimana bakteri menyesuaikan diri dengan substrat dan kondisi lingkungan di sekitarnya yaitu pada hari ke-1. Kemudian dilanjutkan dengan fase log yaitu pada hari ke-3 dimana pada fase ini bakteri berkembang dengan sangat cepat. Setelah itu pada hari ke-5 dan hari ke-7 terjadi fase stasioner. Dan waktu selanjutnya merupakan fase kematian. Pada fase ini sebagian populasi jasad renik mulai mengalami kematian karena beberapa sebab antara lain nutrien di dalam medium sudah habis, energi cadangan di dalam sel habis [13]. Sehingga penambahan rasio Zymomonas mobilis lebih efektif dalam menghasilkan bioetanol dibandingkan Saccharomyces cerevisiae. Pada penelitan ini diperoleh kenaikan yield bioetanol yang tertinggi sebesar $6,31 \%$ pada penggunaan perbandingan mikroba 2:1 (Zymomonas: Saccharomyces) (v/v).

\section{Kesimpulan}

Berdasarkan penelitian yang dilakukan dapat disimpulkan bahwa rasio penambahan mikroba dengan perbandingan 2:1 (Zymomonas mobilis : Saccharomyces cerevisiae) (v/v) pada konsentrasi gula reduksi sisa yaitu $0,767(\mathrm{~g} / \mathrm{ml})$ memberikan yield bioetanol yang tertinggi yaitu sebesar 6,311\% pada waktu fermentasi 3 hari.

\section{Daftar Pustaka}

[1] A.A.N Firmana dan Siti Tjahjani. Karakterisasi Hasil dan Penentuan Laju Reakso Fermentasi Bonggol Pisang (Musa paradisiaca) Menjadi Etanol Dengan Saccharomyces cerevisiae. UNESA Journal Of Chemistry. Vol.3, No.3.2014

[2] A. Ernes dan Agustin Krisna Wardani. Pembuatan Bioetanol Dari Pati Biji Nangka Oleh Zymomonas mobilis CP4 (Kajian Konsentrasi Inokulum dan Amonium Sulfat. Jurnal Agrina. Vol.01/No.01. 2014

[3] A. Limayem, Steven C. Ricke. Lignocellulosic Biomass for Biothanol Production : Curret Perspectives, Potential Issue and Future Prospects. Journal Progress in Energy and Combustion Science-Elsever. Vol 38. Hal. 449-467. 2012

[4] A.N Idiawati, dan Rudiyansyah. Pembuatan Bioetanol Menggunakan Zymomonas Mobilis dari Limbah Tongkol Jagung. Jurnal Kimia Khatulistiwa. Vol. 4(2). ISSN 2303-1077. 2015

[5] A.Rasyidi Fachry., Puji Astuti dan Tri Gita Puspitasari. Pembuatan Bietanol Dari Limbah Tongkol Jagung Dengan Variasi Konsentrasi Asam Klorida Dan Waktu Fermentasi. Jurnal Teknik Kimia Sriwijaya . No.1, Vol 19. 2013

[6] F.Talebnia, Dimitar Karakashev, Irini Angelidaki. Production of Biothanol From Wheat Straw : An Overview On Pretreament, Hydrolysis and Fementation. Journal Bioresourse Technology - Elsevier. Vol 101, Hal : 4744-4753. 2012

[7] F.Merina dan Yulinah Trihadiningrum. Produksi Bioetanol Dari Eceng Gondok 
(Eichhornia crassipes) Dengan Zymomonas mobilis dan Saccharomyces cerevisiae. Prosiding Seminar Nasional Manajemen Teknologi XIII. 2011

[8] I.Truaswaati dan Lani Nurhayati. Pembuatan Bioetanol Gel Sebagai Bahan Bakar Alternatif Pengganti Minyak Tanah. Jurusan Teknik Kimia, Fakultas Teknik Universitas Diponegoro : Semarang. 2014

[9] J.Itelima, A.Ogbonna, S.Pandukur, dkk. Simultaneous Saccharification and Fermentation of Corn Cobs to Bio-Ethanol by Co-Culture of Aspergillus Niger and Saccharomyces cerevisiae. Internasional Journal Of Enviromental Science and Development. Vol 4, No.2. 2013

[10] K. Zhang, Feng, H. Fermentation Potentials of Zymomonas Mobilis and its Application in Ethanol Production From Low-Cost Raw Sweet Potato. African Journal of Biotechology. 9.37. Hal: 61226128. 2011

[11] M.A Kusumaningati, Sri Nurhatika dan Anto Muhibuddi. Pengaruh Konsentrasi Inokulum Bakteri Zymomonas mobilis dan Lama Fermentasi Pada Produksi Etanol dari Sampah Sayur dan Buah Pasa Wonokromo Surabaya. Jurnal Sains dan Semi Pomits. Vol 2, No.2. 2013

[12] M. Balat, Havva Balat, Cahide Oz. Progress in Bioethanol Processing. Journal Progress In Energy And Combustion Science-Elsever. Vol 34, Hal : 551-573. 2011

[13] Nasrun, Jalaluddin dan Mahfuddhah. Pengaruh Jumlah Ragi dan Waktu Fermentasi Terhadap Kadar Bietanol yang Dihasilkan dari Fermentasi Kulit Pepaya. Jurnal Aplikasi Teknologi Pangan. Vol. 1, No.2. 2012

[14] P.P Utomo. Pemanfaatan Nanas (Ananas comosus) Sebagai Bahan Baku Pembuatan Bioetanol Dengan Metode Sakarifikasi Dan Fermentasi Serentak. Jurnal Biopropal Industri. Vol.02, No.01. ISSN 2089-0877. 2011

[15] R Endah, Dyah., Margono, Sunu H Pranolo, Budai Setiani, dan Anni Nurhayati. Bioethanol from Sorghum Grain (Sorghum bicolor) with SSF Reaction Using Biocatalyst Co-immobilization Method of Glucoamylase and Yeast. Journal Energy Procedia 68, Hal. 132 137. 2015

[16] S. Bahri Fitriani, Nurhaeni. Produksi Bioetanol Tongkol Jagung (Zea Mays) dari Hasil Proses Delignifikasi. Jurnal of
Natural Science. Vol 2(3), Hal: 66-74. ISSN: 2338-0950. 2013)

[17] Sipriyadi, S.Si, M.Si. Thesis, Pembuatan Nira Nipah (Nypa Fruticans) untuk Produksi Bioetanol Menggunakan Bakteri Zymomonas mobilis dan khamir Pichia kudriavzeavii.Universitas Bengkulu, Bengkulu, 2013.

[18] S. Kim, Bruce E.Dale. Global Potential Bioethanol Production From Wasted Crops And Crop Residues. Journal Biomass and Bioenergy-Elsever. Vol 26 : Hal: 361-375. 2011

[19] S.K Wahono, Vita Taufika Rosyida, dkk. Optimization of Simultaneous Saccharification and Fermentation Incubation Time Using Cellulose Enzyme for Sugarcane Bagasse on The SecondGeneration Biothanol Production Technology. Journal Energy ProcediaElsevier. Vol 65, Hal : 331-336. 2014

[20] Sumindar. Skripsi, Produksi Bioetanol Dari Limbah Tanaman Jagung Melalui Sakarifikasi dan Fermentasi Simultan dengan Kultur Campuran SaccharomycesCereviseae dan Pichia Stipitis. Fakultas Teknologi Pertanian, Institut Pertanian Bogor : Bogor. 2010.

[21] T.Paschos, Charilaos Xiro dan Paul Christako poulus. Simultaneous Saccharification and Fermentation by CoCultures of Fusarium Oxysporum and Saccharomyces cerevisiae Enhances Ethanol Production From Liquefied Wheat Straw at High Solid Content Elsevier Publishing, www.elsevier. om Industrial Crops and Production-Elsevier. Vol.76: 789-802. 2013

[22] Victor. Skripsi, Pembuatan Bioetanol Dari Ubi Kayu (Manihot utilissima Pohl.) Dengan Jamur Aspergillus awamori Dan Ragi Saccharomyces cerevisia. Fakultas Farmasi. Universitas Sumatera Utara : Medan. 2010.

[23] V.R Reis, Ana Teresa Burlamauqui Faraco Antonangelo, dkk. Bioethanol Strain of Saccharomyces cerevisiae Characterised by Microsatellite and Stress Resistance. Brazil Journal of Microbiology-SBM (Sociedade Brasileira De Microbiologia). No.of Pages 7. 2016 